\title{
INFLUENCE OF DRAMA REHEARSALS IN REGULATING STUDENTS' BEHAVIOUR AND MANAGEMENT OF DISCIPLINE IN SECONDARY SCHOOLS IN CENTRAL REGION, KENYA
}

\author{
Wambugu Pachomius ${ }^{1 \mathrm{i}}$, \\ Zachary Njagi Ndwiga ${ }^{2}$, \\ Rebecca Wachira ${ }^{3}$ \\ ${ }^{1} \mathrm{PhD}$ Candidate, \\ Kenya Methodist University, \\ Kenya \\ ${ }^{2}$ Dr., Department of Education, \\ University of Embu, \\ Kenya \\ 3Dr., Department of Theology, \\ Religious Studies and Counselling, \\ Kenya Methodist University, \\ Kenya
}

\begin{abstract}
:
The use of drama rehearsals as a tool for inculcating discipline among students had been investigated by a number of scholars and education practitioners on global, continental and regional levels. However notable that drama rehearsals as a tool for inculcating discipline could be overlooked as a result of its demands, such as time. Therefore, purpose of the study was to determine effectiveness of drama rehearsals as a strategy in the management of discipline in secondary schools in central region, Kenya. The study used descriptive survey design. The target population was 79 deputy principals, 79 drama teachers, and 1888 drama students and non-drama students in secondary school in Central Region, Kenya. Both the census technique and random sampling were used to get a representative sample size of 419 respondents. Data was collected from the respondents using pretested questionnaires and was analyzed using descriptive and inferential statistical techniques with the aid of Statistical Package for Social Scientists (SPSS) and then interpreted. The study found that the relationship between drama rehearsals and management of discipline among secondary school students was significant. The study therefore recommended that there was need to for school administrators to facilitate more drama rehearsals in order to improve the levels of discipline among students. This will improve their communication skills and as a result bring more rapport between the students and administrators.
\end{abstract}

i Correspondence: email honproject106@gmail.com 
Keywords: drama rehearsals, management of discipline students' behaviour

\section{Introduction}

Discipline is an important component of human behaviour. In functional organizations, it is acknowledged that without it organizational goals can hardly be achieved (Ouma, Simatwa, \& Serem, 2013). In the context of a school system, a disciplined student is that student whose behaviours and actions conform to the predetermined rules and regulations of the school (Ali, Dada, Isiaka, \& Salmon, 2014). Discipline is widely acknowledged to be essential for creating a positive school climate conducive to sound academic performance (Mohamed \& Yunus, 2017). It is a basic requirement for successful teaching and learning in schools and a subject of concern for teachers (Eshetu, 2014). However, indiscipline among secondary school students remains as a significant challenge in virtually all countries globally despite the various educational reforms instituted at national and international levels. According to Tan and Yuanshan (2014), the problem of indiscipline in schools is a global issue of great concern, traversing political, economic, geographical, racial and even gender boundaries.

For instance, in the US, Dalporto (2013) reported high levels of violence in schools, bullying and dropping out. Prevalence of 'deviance' and 'violence' among high school students has been reported in England (Hyden, 2009). Similarly, indiscipline in school manifested in the form of violence has been reported in High schools in across Europe, for example, Germany (Fuchs \& Schmalz, 2009), France (Blaya, 2012), and Portugal (Formosinho, Taborda \& Fonseca, 2008). Standards of discipline have reported to be deteriorating in Indian secondary schools (India Parenting Online, 2007). Indiscipline among secondary school students in Nigeria is still high and has been substantially attributed to substance abuse (Nakpocha, 2010), school factors and society and student attributes (Ali, Dada, Isiaka \& Salmon, 2014). In Ghana, Gyan et al., (2015) reports that almost all the secondary schools face disciplinary problems. Studies in the Ethiopian context disclose that students' disciplinary problem in secondary school in the country has been growing in levels of seriousness over time (Alemayehu, 2012; Eshetu, 2014). Kenya's education sector is no stranger to student indiscipline among secondary school students that has at times culminated into mass student unrest and destruction of property and even loss of lives. In 2016, close to 100 secondary schools were set ablaze by students in what appears to be unclear circumstances (National Crime Research Centre, 2017).

The few studies cited above point out to serious discipline management problems in secondary schools that need systemic redress that go beyond educational reforms in order to find a lasting solution to the problem of indiscipline. The cost of the student indiscipline is incalculable in terms of human capital waste and infrastructural damage. Therefore, student indiscipline as it stands today constitutes a significant threat to not only the students' future prospects and the stability of the education sector but also the country at large whose competitiveness as an international labour market risks being 
substantially impaired. In Kenya, a myriad of educational reforms has been instituted in the governance and administration of education in the country, and a key reform in terms of discipline management has been the abolishment of corporal punishment as a way of managing discipline among secondary school children. In place of corporal punishment, the government advocated for guidance and counseling of students in schools, as a strategy to manage discipline. As a result, students were expected to be fully responsible in following school rules and regulations, being more skillful in carrying out of school duties and therefore bringing about low occurrence of indiscipline cases. Notwithstanding corporal punishment ban, cases of indiscipline in secondary schools had been on the upward trend. Subsequently, several alternative disciplinary mechanisms other than physical sanctions have since emerged to address the failing disciplinary standards in secondary schools in the country. Among these are guidance and counseling, peer counseling, teacher- student conferences, collaborative decision making, suspension, expulsion (Mulwa, 2014; Agesa, 2015; Ngunju, 2017).

However, drama though widely practiced in secondary schools across the country has not been examined for its effects on discipline management among secondary school students in the country. Indeed, extant literature intimates that apart from its effects on academic performance of the students, drama participation could have significant effects on behavioral modification of the students and, hence, become instrumental in discipline management. Drama has been defined as the specific mode of fiction represented in performance: a play, opera, mime, ballet, etc., performed in a theatre, or on radio or television (Fergusson, 1968). Drama is a communicative event that seeks to develop and personify real or imagined characters and events in a melodramatic fashion to an audience. Indeed, the ancient philosopher Aristotle argues that actors in drama aim to mimic actions (Diamond, 1997). In the African context, Ngugi wa Thiongo (1981) explains that drama was a tool of moral instruction as well as a strict matter of life and death and communal survival. This view by Ngugi wa Thiongo provides insight into the possibilities of drama being used in schools to manage student discipline. Subsequently, drama practice has been found to be instrumental both to the behavioral modification of students and their academic performance in secondary schools in various contexts across the globe (Subaşi, Aydin \& Seven, 2016; Şimşek et al., 2010; Avinç, Çam \& Özkan, 2009; Paredes, 2010; Vietnam, Nguyen \& Do, 2017; Braund \& Ahmed, 2019). Alaba and Tayo (2014) study on Socio-Drama Learning Package role in Promoting Environmental Knowledge and Behaviour of Secondary Schools Students in Osun State, Nigeria revealed that the interactive drama package was effective in the teaching of environmental education and useful in broadening students' knowledge about environmental pollution. This approach also enhanced the academic performance of the students and changed their attitude positively.

\subsection{Statement of the Problem}

With the myriad of educational reform in the governance and administration of education in Kenya, there came into place the abolishment of corporal punishment as a 
way of managing discipline among secondary school students. As a result, students were expected to be fully responsible in following school rules and regulations, being more skillful in carrying out of school duties and therefore bringing about low occurrence of indiscipline cases. Notwithstanding corporal punishment ban, cases of indiscipline in secondary schools had been on the upward trend. Consequently, there was need for the stakeholders in the secondary education to device and implement alternative strategies in place of the traditional methods. The possibility of exploring drama as such a possible strategy was considerable. In drama, there are responsibilities and skills that are allocated and instilled to students. The responsibilities and skills are meant to inculcate responsible behavior in students. Of key interest to this study is to ascertain whether rehearsal of these drama responsibilities and skills could be instrumental in the management of student discipline. Secondary schools from Central region in Kenya are known as formidable competitors in the Kenya National Drama Festivals (KNDF) competing successfully at every stage of the competitions over the years. Their preparation for these events is characterized by extensive rehearsals. However, these drama rehearsals have not been empirically examined for their effect on management of discipline among the secondary schools in the Region. This paper, therefore, undertook to examine this closely.

\subsection{Objective of the Study}

The study, therefore, the study was guided by the objective;

- To assess drama rehearsals as a way of inculcating discipline among students in secondary schools in Central Region, Kenya.

\section{Literature Review}

\subsection{Drama Rehearsals and Inculcating Discipline among Students}

The use of drama rehearsals as a tool for inculcating discipline among students had been investigated by a number of scholars and education practitioners on global, continental and regional levels. Drama tools are essential in assets in the management of societal and specifically students' discipline. Dramen (2012) says drama is performed in theatre. According to Dramen most historians and critics would agree that the following elements are essential to theatre; language, impersonation and audience. This study viewed language and impersonation as dramatic communication tools which are assumed to influence the discipline of students. Tauber (2007) has talked of discipline being a real problem. He has further reiterated that lack of discipline is one of the biggest problems in public schools. Literature reveals that student indiscipline is experienced in schools globally (Ali, Dada, Isiaka \& Salmon, 2014). Globally, studies have been undertaken to investigate how drama rehearsal activities can be used in instilling discipline at secondary school, with Kuh (2006) study recommending that due emphasis should be given to co-curricular activities alongside the curricular activities for all-round development of children. 
The participants in the co-curricular activities are guided by a staff member or any other adult with knowledge and experiences. It was however notable that drama rehearsal as a tool for inculcating discipline could be overlooked as a result of its demands, such as time. This fact had been investigated by McMaster (1998) whose study showed that despite drama's strong association with and support of the multiple ways of learning, sometimes teachers avoided use of drama because of the fear that much preparation time would be required. In Africa, researchers have pointed out the seriousness of indiscipline in schools in various countries. The countries include Ghana, South Africa Botswana, Nigeria and Tanzania (Masitsa, 2008). Umezinwa and Elendu (2012) for instance, observed that indiscipline among learners in Nigeria was high and experienced at all levels including primary schools.

Further, drama could be used to make learning and school life more accommodative to the student by making learning enjoyable. This is a view that has been supported by Triguero (2015) who observed that drama can help the teacher in achieving reality in several ways like overcoming the students' resistance to learning a new language by making the new language more enjoyable. MacMaster (as cited in Lom, 2012) advocated that drama can be an invaluable teaching method for it supports all aspects of literacy development. Students who are involved in Kenya National Drama Festival do memorize, rehearse and later perform in front of adjudicators. Such students were likely to acquire a strong sense of confidence and self-discipline compared to those who didn't. Wahl (2002) believes tapping into these intelligences is the key element to making drama effective in teaching. According to Buchanan (2010) drama helps students in developing their confidence and also useful for empathy development. This involves the aspect of understanding someone else's sense and point of view. This is further collaborated by Booth (2008), Ikagami (2000), Johnson and Confer (2004), who reported that participation in co-curricular, especially drama, helped in reducing the anxiety level of the participants.

Studies similar to the above studies had been undertaken locally in Kenya. For instance, lack of discipline in schools had been one of the challenges facing schools, a situation that could be mitigated by actively engaging the learners in co-curriculum activities such as drama rehearsals and games (Njoroge \& Nyabuto, 2014). Additionally, a study by the Kenya National Examinations Council (KNEC) supported these findings by revealing that between $90 \%$ and $100 \%$ of teachers in primary schools in Kenya encountered disciplinary problems among their pupils (KNEC, 2010), a situation that could be mitigated by actively engaging the students in drama rehearsals, drama competition and games. These studies had however not actively explored the extent to which drama rehearsal could be used as a tool to mitigate on indiscipline among students. The researcher would thus seek to explore this.

A different view of use of drama in instilling discipline had been presented by authorities as a tool of preparing and modelling the student to the future being. As such, drama also presents a venue to prepare the student for the realities of life outside school. This is as argued out by Elizabethan and Jacobean (2008) who are of the view that drama is an important tool for preparing students to live and work in a world that is increasingly 
team-oriented rather than hierarchical. The ability to understand others' motives and choices is also critical according to Kempe and Nicholson (2007). Drama can help build responsible global citizens. Drama helps students to comprehend the world they live in and construct their knowledge and increases the chances for children to express themselves independently in any subject area, including reading (Booth, 1985). Drama activity is not wasted time (Rose, Parks, Androes, \& McMahon, 2000) because students learn to develop language skills necessary in studying. According to Kempe and Nicholson (2007), drama provides specific opportunities for literacy development giving students the chance to use all skills in decoding meaning and understanding the feelings of others.

\section{Methodology}

\subsection{Research Philosophy and Design}

The present study was grounded on a positivist philosophy. The positivist approach was adopted due to the level of inquiry and the empirical rigour using both qualitative and quantitative methods demanded to satisfy the inquiry (Žukauskas, Vveinhardt \& Andriukaitiené, 2018). In line with this, descriptive survey design was used in the study. The design was appropriate in the sense that the study was geared towards determining the extent to which the discipline of students was influenced by drama rehearsals and how this affected the management of students' discipline by the school administration.

\subsection{Location of Study}

The study was carried out in Central Region, Kenya. The Central Kenya region consists of the five counties constituting the former central province of the Republic of Kenya, namely; Murang'a, Nyeri, Kiambu, Nyandarua, and Kirinyaga. Under the current constitutional dispensation, the region is administered by the regional commissioner who represents the national government (GoK, 2010). According to Regional Coordinator Education's Office (2017), the region has a total of 902 secondary schools. The region's teacher to student ratio is 1:22 for public high schools. According to statistics obtained from Drama secretariats in the five counties (2017), 400 schools in the region took part in drama festival at the sub county levels (Central Region Education Headquarters, 2018) indicating that there was considerable engagement in drama by the schools in the region. Further, schools from the region demonstrate high levels of performance at the Kenya National Drama Festival and consistently feature at the national levels where they are able to compete successfully with schools from other regions in the country. Further, public secondary schools in Central region are diverse in terms of students and teacher population can be taken as being representative of the entire country.

\subsection{Target Population of the Study}

This study targeted 79 public secondary schools in the region that have consistently participated in the Kenya National Drama Festival competitions up to the sub county 
levels and beyond in the last five years. From these, the accessible population comprised of 83 deputy principals (some secondary schools had more than one deputy principal); 79 drama teachers, and 1250 students of who 944 were active drama students and 306 were non drama students. This translated to 12 drama students and 3 non-drama students per school respectively. The students were drawn from form two, three and four in secondary schools due to the fact that they had considerable experience in high school drama and student life and could give informed conclusions on the study questions. Form one students are new in school and therefore were not effectively involved.

\subsection{Sampling Techniques and Sample Size}

In this study, both purposive and systematic random sampling were used in the study to obtain maximum variation while ensuring respondent specifity and randomness (Oso \& Onen, 2009). purposive sampling was used to select all the 79 public secondary schools that had participated in the Kenya National Drama Festival competitions up to the sub county levels and beyond in the last five years. Purposive sampling was also used to select all the deputy principals and drama teachers in these schools since their population was small. For the large population of students, 1250, systematic random sampling was used. The sample size of the students was, thus, determined via the formula supplied by Kathuri and Pals (1993), thus;

$$
n=\frac{\chi^{2} N p q}{\sigma^{2}(N-1)+\chi^{2} p q}
$$

Where; $\mathrm{n}=$ required sample size, $\mathrm{N}=$ the given population size of the students, $1250, P=$ population proportion, assumed to be $0.7, q=1-p=0.3, \quad \sigma^{2}=$ the degree of accuracy whose value is 0.05 and $\chi^{2}=$ table value of chi-square for one degree of freedom, which is 3.841. Substituting this into the formula yielded a student sample size used in the study was 257. To this sample size was added 83 deputy principals and 79 drama teachers bringing the entire sample size to 419 respondents.

\subsection{Data Collection Instruments}

The study used questionnaires and document analysis to collect data for the study. Questionnaires in form of rating scales were used to collect data on drama and discipline management of the selected students. Secondary information was obtained from documents from drama secretariat offices and from the public secondary schools across the Central Region of Kenya. The data questionnaires were pilot tested in order to establish validity and reliability before they were finally used in collection of data. The pilot data results were analysed in order to assure clarity.

\subsection{Data Analysis}

Statistical Package for Social Scientists (SPSS) version 22.0 was used to conduct initial data analysis using simple descriptive statistical measures such as, mean, standard deviation and variance to give glimpse of the general trend. Additionally, inferential 
statistics involving both correlation and multiple regression was conducted to determine associations between the dependent variable and the independent variable, as under;

$\mathrm{Y}=\mathrm{B}_{0}+\mathrm{B}_{2} \mathrm{X}_{2}+\mathrm{e}$

Where, $\mathrm{Y}=$ Management of students' discipline, $\mathrm{B}_{0}=$ Constant, $\mathrm{B}_{2}=$ Change in $\mathrm{Y}, \mathrm{X}_{2}=$ Drama skills and e = error

\section{Results and Discussion}

\subsection{Introduction}

The researcher administered 419 questionnaires to all the sampled respondents for this study. Out of these, a total of 335 questionnaires representing an overall response rate of $80 \%$ which was high and was, therefore, acceptable for the purposes of the study as indicated by Babbie (2004).

\subsection{Drama Rehearsals vs Management of Discipline}

The objective of the study was to examine the assess drama rehearsals as a way of inculcating discipline among students in secondary schools in Central Region, Kenya. This variable was described in terms of; Language and communication development, Allround development, Literacy development, Confidence and intelligence. The results were obtained from all respondents. A five point Likert scale was used to rate responses of this variable and it ranged from; 1 = strongly disagree to $5=$ strongly agree and was analysed on the basis of the mean score and standard deviation.

Table 1: Drama Rehearsals on Students' Discipline Management

\begin{tabular}{llccccccc}
\hline Drama Rehearsals & Respondent & SD & D & N & A & SA & Mean & Std.Dev \\
\hline Language & Deputies & 9.1 & 0 & 9.1 & 40.9 & 40.9 & 4.05 & 1.16 \\
Development & Drama Teachers & 0 & 0 & 6.7 & 33.3 & 60 & 4.53 & 0.64 \\
& Drama Students & 5.6 & 6.3 & 16.8 & 32.9 & 38.5 & 3.92 & 1.145 \\
& Non-Drama Students & 5.5 & 7.3 & 36.4 & 27.3 & 23.6 & 3.56 & 1.102 \\
\hline Communication & Deputies & 0 & 0 & 18.2 & 31.8 & 50 & 4.32 & 0.771 \\
Development & Drama Teachers & 0 & 0 & 13.3 & 26.7 & 60 & 4.47 & 0.743 \\
& Drama Students & 5.6 & 7 & 19.6 & 37.8 & 30.1 & 3.8 & 1.117 \\
& Non-Drama Students & 3.6 & 1.8 & 7.3 & 34.5 & 52.7 & 4.31 & 0.96 \\
\hline All-round & Deputies & 0 & 0 & 22.7 & 27.3 & 50 & 4.27 & 0.817 \\
Development & Drama Teachers & 0 & 6.7 & 6.7 & 40 & 46.7 & 4.27 & 0.884 \\
& Drama Students & 4.9 & 11.9 & 24.5 & 30.1 & 28.7 & 3.66 & 1.157 \\
& Non-Drama Students & 0 & 12.7 & 14.5 & 41.8 & 30.9 & 3.91 & 0.986 \\
\hline Literacy & Deputies & 0 & 0 & 13.6 & 50 & 36.4 & 4.23 & 0.677 \\
Development & Drama Teachers & 0 & 6.7 & & 53.3 & 40 & 4.27 & 0.799 \\
& Drama Students & 9.8 & 11.2 & 22.4 & 25.2 & 31.5 & 3.57 & 1.303 \\
& Non-Drama Students & 9.1 & 16.4 & 18.2 & 34.5 & 21.8 & 3.44 & 1.259 \\
\hline Confidence & Deputies & 0 & 0 & 13.6 & 45.5 & 40.9 & 4.27 & 0.694 \\
Development & Drama Teachers & 0 & 0 & 0 & 40 & 60 & 4.6 & 0.507
\end{tabular}


Wambugu Pachomius, Zachary Njagi Ndwiga, Rebecca Wachira

INFLUENCE OF DRAMA REHEARSALS IN REGULATING STUDENTS' BEHAVIOUR AND

MANAGEMENT OF DISCIPLINE IN SECONDARY SCHOOLS IN CENTRAL REGION, KENYA

\begin{tabular}{llccccccc}
\hline & Drama Students & 4.9 & 8.4 & 23.8 & 23.1 & 39.9 & 3.85 & 1.183 \\
& Non-Drama Students & 3.6 & 12.7 & 23.6 & 29.1 & 30.9 & 3.71 & 1.149 \\
\hline Intelligence & Deputies & 0 & 0 & 27.3 & 59.1 & 13.6 & 3.86 & 0.632 \\
Development & Drama Teachers & 0 & 6.7 & 6.7 & 26.7 & 60 & 4.4 & 0.91 \\
& Drama Students & 1.4 & 2.8 & 12.6 & 25.2 & 58 & 4.36 & 0.907 \\
& Non-Drama Students & 3.6 & 14.5 & 21.8 & 38.2 & 21.8 & 3.6 & 1.099 \\
\hline
\end{tabular}

\subsubsection{Language Development during Drama Rehearsals on Management of Students' Discipline}

Language development is a higher level cognitive skill involving audition and oral abilities in humans to communicate verbally individuals' wants and needs. It supports the ability of the learner to communicate, and express and understand feelings. It also supports the learners' thinking ability and helps them develop and maintain relationships (Bornstein \& Putnick, 2012). The respondents were, therefore, asked concerning the influence of language development during drama rehearsals on management of students' discipline among secondary school students. The findings in Table 1 indicated that majority $(40.9 \%)$ of the deputy principals and $60 \%$ of the drama teachers strongly agreed with this opinion. However, in comparison, fewer drama students $(38.5 \%)$ strongly agreed with the statement. Most of the non-drama students $(36.4 \%)$, however, were uncertain about the effects of language development during drama rehearsals on management of students discipline.

These findings imply that for the most part, there was a strong feeling among the respondents that language development during drama rehearsals was important in the management of students discipline in the area. This was so as drama encouraged students to learn new language (Triguero, 2015) and to use decent language in addressing issues (KNDF, 2017). The findings concur with Ula (2008) who asserted that drama creates a need to learn language, and puts more responsibility on the learner as opposed to the teacher, therefore, implying that the student will necessarily change his behaviour to conform to the new language demands. Krauss and Chiu (2000) observed that learning a language goes beyond memorizing vocabulary and gaining knowledge of proper grammar; it often requires adopting an entirely new way of thinking. And as one's thought patterns change, behavior may also be modified. Thus, the effect of language development through could result into behaviour modification of students which manifests also in terms of their discipline.

\subsubsection{Communication Development during Drama Rehearsals on Management of Discipline}

Communication is the process through which, concepts, ideas and messages are transmitted from one point to another and feed back received. Communication should perform three functions namely, increase understanding, enhance a spirit of solidarity and to improve the capacity of men and women. Hence, communication development is communication with a social conscience which goes beyond making information available to people but also building understanding between and among participants 
who must follow a process. Therefore, the present study asked the respondents their views regarding the influence of communication development during drama rehearsals on management of students' discipline among secondary school students. The respondents though did not considerably vary on their opinions of communication development during drama rehearsals. Majority of the deputy principals (50\%), drama teachers $(60 \%)$ and non-drama students $(52.7 \%)$ strongly felt that communication development during drama rehearsals influenced management of students discipline among secondary schools in the area. However, fewer drama students (37.8\%) agreed with this view.

These findings implied that communication learnt through drama rehearsals could considerably influence the management of discipline among the students in the region was managed. The KNDF Adjudication Reports (2015) cited basic communication skills among others as instrumental in advancing the discipline elements of the students. Without good communication, it is difficult to manage discipline among students as explained by Kindiki (2009) who found that ineffective communication results in conflict, chaos, misunderstanding and lack of confidence in school administration. Okumbe (2007) also pointed out that communication helps to control the behaviour of the teachers, students and non-teaching staff. Through communication, the students are informed about their expected behaviour within an educational organization. Likewise, the consequences of deviant behaviour are also specified and understood through communication. Therefore, learning communication skills through drama participation could enhance discipline among students in schools.

\subsubsection{All-round Development during Drama Rehearsals on Management of Students' Discipline}

An all-round student is a learner that is generally good at a wide range of things, either in one field or many such as social, moral \& educational. It also means that we focus and emphasize more than the academic development of the child (Kususanto, Ismail \& Jamil, 2010). In relation to drama, Kuh (2006) recommended that due emphasis should be given to all-round development of leaners through co-curricular activities. It was important, therefore, to establish the influence of all-round development during drama rehearsals on management of students' discipline among secondary school students. Therefore, the respondents were asked whether all-round development during drama rehearsals on management of students' discipline among secondary school students. The findings indicated that while majority of the deputy principals (50\%) and drama teachers (46.7\%) strongly felt that all-round development during drama rehearsals influenced management of students' discipline among secondary school in the area, fewer drama students (30.1\%) and non-drama students (41.8\%) agreed with this opinion.

The implication of theese findings was that there was general agreement on allround development achieved through drama rehearsals influenced management of discipline among the students in the region.Smithers and Eaton (2017) asserted that allround student is able to become a universally normed and disciplined individual within 
a dysfunctional society. In a study on moral competence on positive youth development, Ma (2012) also opined that the best and the most practical ways to promote moral competence in adolescents are not to construct a teaching package focusing solely on moral competence. Instead, a comprehensive and all-round positive youth development program is a better choice. Shek and Ma (2007) had also argued that in order for the school-based program to be successful in helping students to increase their moral and prosocial behaviours and reduce their antisocial behaviours, the program should be based on all-round or whole-person development and the length of the program should be sufficiently long.

\subsubsection{Literacy Development during Drama Rehearsals on Management of Students' Discipline}

Literacy is essential to developing a strong sense of well-being and citizenship (Leki, 2017). Students who have developed strong reading skills perform better in school and have a healthier self-image. Literacy development refers to the on-going development of skills needed to successfully communicate through written communication (McBrideChang, 2014). MacMaster (as cited in Lom, 2012) advocated that drama can be an invaluable teaching method for it supports all aspects of literacy development. Hence, the respondents in the current study were asked to rate the influence of Literacy development during drama rehearsals on management of students' discipline among secondary school students. Majority (50\%) of the deputy principals and drama teachers (53.3\%) agreed with this view. However, most of the drama students $(31.5 \%)$ strongly supported this view while most non-drama students (34.5\%) agreed with the opinion that literacy development during drama rehearsals influence management of students discipline among secondary school students.

This finding implies that there was a feeling among most respondents that developing literacy competencies during drama rehearsals could improve the management of students discipline among secondary school students. These findings therefore support those of Garwood et al., (2017) whose study indicated that higherquality classroom management in the first years of school was significantly related to higher scores on standardized measures of reading achievement for students exhibiting emotional and behavioral disorders (EBD). In other words, as their literacy skills improved, their EBD declined. Similarly, Dobbs-Oates et al., (2011) found that emergent literacy development positively predicted learner's task orientation and behavior management. According to Kempe and Nicholson (2007), drama provides specific opportunities for literacy development giving students the chance to use all skills in decoding meaning and understanding the feelings of others. Therefore, the present study shows that literacy development through drama rehearsals can be used as a method of instilling discipline among students. 


\subsubsection{Confidence Development during Drama Rehearsals on Management of Discipline}

Confidence comes from feelings of well-being, acceptance of your body and mind (your self-esteem) and belief in your own ability, skills and experience (Eşkisu, 2014).According to Buchanan (2010) drama helps students in developing their confidence and also useful for empathy development. This involves the aspect of understanding someone else's sense and point of view. Therefore, the present study sought to find out the influence of confidence development during drama rehearsals on management of students' discipline among secondary school students by asking the respondents whether, indeed, confidence development during drama rehearsals on management of students discipline. The findings indicated that majority $(45.5 \%)$ of the deputy principals agreed while majority of the drama teachers (60\%) strongly agreed with this opinion. However, fewer drama students (39.9\%) and non-drama students (30.9\%) strongly agreed with the statement.

This implies that confidence development during drama rehearsals was critical to management of students discipline among secondary school students. These findings agree with Ballane (2019) who found that building self-confidence among learners through constructive criticism while dealing with an inevitable failure in the society results in resolving all the challenges and unethical behaviours among students. In the context of drama rehearsals, this is ideally achieved through constructive criticisms rather than outright dismissal. This inculcates in the student belief in his abilities mistakes notwithstanding. Without the belief that one can produce desirable results by persisting in a course of behaviour or changing an unsuccessful one, there is minimal motivation to act. Students who are involved in Kenya National Drama Festival do memorize, rehearse and later perform in front of adjudicators. Such students were likely to acquire a strong sense of confidence and self-discipline compared to those who did not (KNDF, 2017).

\subsubsection{Intelligence Development during Drama Rehearsals on Management of Discipline}

Intelligence development is the learner's ability to think and reason. It's about how they organize their minds, ideas and thoughts to make sense of the world they live in. Gardener (2003) argues that drama is effective because it taps different intelligences possessed by students to help them learn and realize success in academic situations and at the same time in their life. The respondents in the current study were, therefore, asked whether they believed that intelligence development during drama rehearsals influences the management of students' discipline among secondary school students. The results showed that majority (59.1\%) of the deputy principals agreed while most of the drama teachers $(60 \%)$ and drama students (58\%) strongly agreed with this view. However, there was little agreement with this opinion among most of the non-drama students (38.2\%).

This implied that there was considerable support among the respondents that intelligence development during drama rehearsals influenced management of students discipline. Wahl (2002) opined that tapping into the intelligence development is the key element to making drama effective in teaching. Dweck (2012) in the Implicit Theories of 
Intelligence asserts that when a learner believes that intelligence is dynamic and possible to improve, they will achieve better learning results compared to if they believe it to be fixed and unchangeable (Blackwell et al.2015; Rattan, Good \& Dweck, 2012). The scope of intelligence developed through drama can also include emotional intelligence which is important in discipline as indicated by Ngila and Makewa (2017) who found that students' level of self-discipline positively related to their level of emotional intelligence.

\subsection{Effectiveness of Management of Discipline in Secondary Schools in Central Kenya}

The study sought to determine the status of management of discipline in secondary schools in Central Kenya. This was the dependent variable and was measured in terms of alternative channel of disciplinary tools and low occurrences of indiscipline. The results are presented and discussed as follows.

\subsubsection{Alternative Channel of Disciplinary Tools}

The respondents were asked to state whether drama participation served effectively as an alternative channel of disciplinary tools in the management of discipline among secondary school students. The findings are presented in Table 2.

Table 2: Alternative Channel of Disciplinary Tools

\begin{tabular}{lcccccccc}
\hline Respondent & $\mathbf{N}$ & $\mathbf{1}$ & $\mathbf{2}$ & $\mathbf{3}$ & $\mathbf{4}$ & $\mathbf{5}$ & Mean & Std. Dev \\
\hline Deputies & 57 & 7.1 & 64.3 & 14.3 & 7.1 & 7.1 & 2.43 & 1.016 \\
Drama Teachers & 54 & 0 & 0 & 26.7 & 26.7 & 46.7 & 4.20 & 0.862 \\
Drama Students & 143 & 3.5 & 10.5 & 25.9 & 34.3 & 25.9 & 3.69 & 1.077 \\
Non-Drama Students & 81 & 1.8 & 3.6 & 12.7 & 40 & 41.8 & 4.16 & 0.918 \\
Aggregate & 335 & & & & & & 3.62 & 0.9683 \\
\hline
\end{tabular}

According to the results in Table 2, the aggregate mean, $\mathrm{M}=3.62 ; \mathrm{SD}=0.968$ suggests implies that there was agreement and a low variation on whether drama participation served effectively as an alternative channel in the management of discipline among secondary school students. Specifically, majority of the drama teachers $(46.7 \%)$ strongly supported this view on drama as an alternative channel of discipline, however, majority of the deputy principals $(64.3 \%)$ did disagree with the efficacy of the drama approach as an alternative in management of discipline among students. Most of the drama students $(34.3 \%)$ agreed with the opinion that drama was an effective alternative in management of discipline which was a view shared by most of non-drama students $(41.8 \%)$ who strongly agreed with it.

These findings imply that while there were differing perceptions on the efficacy of drama participation as an alternative channel in the management of discipline among secondary school students, it was still regarded as an important tool in the disciplinary efforts in secondary schools in Central Region of Kenya. These findings agreed with Etesi (2012) who found that alternative discipline management strategies were increasingly effective than the traditional discipline management strategies such as corporal punishment. The findings, however, disagree with Handayani (2015) who argued that 
alternative strategies that are used to inculcate discipline among students in secondary schools have proved to be ineffective.

\subsubsection{Occurrences of Indiscipline}

There was need to establish the status of occurrences of indiscipline among secondary school students. The results are presented in Table 3.

Table 3: Occurrences of Serious Forms of Indiscipline

\begin{tabular}{lcccc}
\hline Type of indiscipline & None at all (\%) & Little (\%) & Much (\%) & Very Much (\%) \\
\hline Strikes & 59 & 17 & 10 & 15 \\
Bullying & 29 & 7 & 36 & 27 \\
Fighting & 50 & 11 & 26 & 14 \\
Threats to teachers & 53 & 22 & 20 & 5 \\
Vandalism & 39 & 27 & 16 & 18 \\
Theft & 15 & 26 & 19 & 40 \\
Substance abuse & 32 & 36 & 11 & 21 \\
Aggregate (\%) & 40 & 21 & 20 & 20 \\
\hline
\end{tabular}

Looking at the results in Table 3, it is evident that the occurence of serious forms of indiscipline among students were not reported as indicated by the aggregate percentage of $40 \%$ compared to those who reported their occurences were little $(21 \%)$, much $(20 \%)$ and very much $(20 \%)$. However, the results suggest that the schools still experienced considerable serious disciplinary challenges among students in terms of theft (40\%), bullying (27\%) and substance abuse (21\%). The decreasing incidences of serious forms of discipline attributable to involvement in drama suggests that as an alternative means of discipline, drama provided a means where students learnt the value of self discipline in some activity they liked participating in. This finding agrees with Were (2014) who noted that dramatic ritual and their related rules and regulations play very significant roles in the management of the community. People restrict themselves to the rules, regulations, values and beliefs of the community. By restricting themselves in these rules and regulations, people are able to discipline themselves and therefore easily managed. Were's view is further collaborated by that of Khamalwa (2004) who notes that a dramatic ritual brings change of status to the entire community. A school is an established community with laid down rules and regulations. During drama activities, there are rules that must be observed in order for the team to be well disciplined.

\subsubsection{Types of Disciplinary Actions taken on Serious Forms of Indiscipline}

Finally, there was need to establish the types of disciplinary actions taken on serious forms of indiscipline among secondary school students. The results are presented in Table 4. 
Table 4: Types of Disciplinary Actions taken on Serious Forms of Indiscipline

\begin{tabular}{lccccccc}
\hline Serious disciplinary action taken & $\mathbf{2 0 1 5}$ & $\mathbf{2 0 1 6}$ & $\mathbf{2 0 1 7}$ & $\mathbf{2 0 1 8}$ & $\mathbf{2 0 1 9}$ & Total & $\mathbf{\%}$ \\
\hline Suspension & 43 & 54 & 38 & 26 & 32 & 193 & 74 \\
Expulsion & 10 & 19 & 15 & 6 & 11 & 61 & 23 \\
Involvement of law enforcement agencies & 1 & 2 & 0 & 3 & 1 & 7 & 3 \\
Total & 54 & 75 & 53 & 35 & 44 & 261 & 100 \\
\hline
\end{tabular}

It is evident from the results in Table 4 that the most common type of disciplinary action taken on serious forms of indiscipline administered in the schools surveyed in Central Region, Kenya over the last five years was suspension (74\%). This was followed by expulsion (23\%) and iinvolvement of law enforcement agencies (3\%). Further, looking at the results, it is evident that there was a marked decrease in suspensions and expulsions of students over the five-year period. Drama skills have also been viewed as a crucial tool for managing the personal discipline. This can be illustrated by Wasambo (2014) who argues that drama has been in the past associated with how man manages himself or herself discipline wise since it has a long history of influence.

According to the Task Force by the Ministry of Education (2001) on discipline and unrest in secondary schools, discipline is influenced by lack of sustaining ideal behaviour in students, economic difficulties, lack of communication between teachers and students and parental influence. However, Booth (2008), Ikagami (2000), Johnson and Confer (2004) aver that participation in co-curricular, especially drama, helps in reducing the anxiety level of the participants. Students who are involved in Kenya National Drama Festival do memorize, rehearse and later perform in front of adjudicators. Such students are likely to acquire a strong sense of confidence and self-discipline compared to those who do not. Further, according to Buchanan (2010) drama helps students in developing their confidence and also useful for empathy development.

\subsection{Regression of Drama Rehearsals and Management of Student Discipline}

Pearson product moment correlation coefficient test was used to investigate whether there existed a significant relationship between drama rehearsals and management of students' discipline in secondary schools in Central Region, Kenya. The analysis was tested at 0.05 level of significance. Findings are presented in Table 5.

Table 5: Regression of Drama Skills and Regulation of Students' Behaviour

\begin{tabular}{|c|c|c|c|c|c|}
\hline & \multicolumn{2}{|c|}{ Unstandardized Coefficients } & \multirow{2}{*}{$\begin{array}{c}\text { Standardized Coefficients } \\
\text { Beta }\end{array}$} & \multirow[t]{2}{*}{$\mathbf{t}$} & \multirow[t]{2}{*}{ Sig. } \\
\hline & B & Std. Error & & & \\
\hline (Constant) & 4.717 & 0.679 & & 6.943 & 0.000 \\
\hline Drama Rehearsals & 0.091 & 0.025 & 0.252 & 3.648 & 0.000 \\
\hline $\mathrm{R}$ & $.252 \mathrm{a}$ & $\mathrm{F}$ & 13.306 & & \\
\hline R Square & 0.064 & Sig. & $.000 \mathrm{~b}$ & & \\
\hline Adjusted R Square & 0.059 & & & & \\
\hline
\end{tabular}

a Dependent Variable: Drama Effectiveness

b Predictors: (Constant), Drama Rehearsals 
The findings in Table 5 shows that there was indeed a significant relationship $(\beta=$ $0.252, p=0.000<p=0.05$ ) between drama rehearsals and management of discipline among students in secondary schools in Central Region, Kenya. The results suggest that there was a moderate but positive relationship between the variables indicating that as things currently stand, the drama rehearsals were instrumental in helping manage students' disciplinary issues in the schools. The r-square $\left(R^{2}=0.059\right)$, further, indicates that the model could explain upto $6 \%$ of the variations in the management of students' discipline in secondary schools in Central Region. It also suggests that the model could improve when more predictive variables were incoporated into the model. Further, from the ANOVA results, it is evident that there is a significant difference between the means ofdrama rehearsals and the mean of variable predicting regulation of students' behaviour in secondary schools in Central Region $\left(\mathrm{F}_{\mathrm{o}^{\prime}}=13.306>\mathrm{F}_{\mathrm{c}}=3.87 ; \alpha<0.05 ; \mathrm{df}=1,333 ; \mathrm{p}=\right.$ $0.000<p=0.000<p=0.05$ ). As such, we conclude that drama rehearsals were important tools of managing discipline among students. Therefore, the resulting model is predicted by;

Management of students' discipline $=4.717+0.091$ Drama Rehearsals

Or simply,

$$
\mathrm{Y}=4.717+0.091 \mathrm{DS}
$$

The findings imply that drama rehearsals were significant in the management of discipline among students. As such, they support the postulation of Njoroge and Nyabuto (2014) that lack of discipline in schools can be mitigated by actively engaging the learners in co-curriculum activities such as drama rehearsals and games. Indeed, drama rehearsals require a lot of discipline in order for the outcome to be good. Students who are involved in Kenya National Drama Festival do memorize, rehearse and later perform in front of adjudicators. Such students are likely to acquire a strong sense of confidence and self-discipline compared to those who do not. Dunn (2007) found that students receiving feedback had higher performance ratings, recorded a more positive attitude toward rehearsal, and were observed off-task a larger percentage of instructional time than students receiving no feedback, with both groups demonstrating lowest off task percentages during group performance activities.

\section{Conclusions}

The study found that drama rehearsals was an important factor in the management of discipline in secondary schools in the area. Drama rehearsals was an important factor in the management of discipline in secondary schools in the area and more focus on drama rehearsals would necessarily translate to higher levels of discipline among the students. Other conclusions drawn from the findings on this objective was that language 
development during drama rehearsals was important in the management of students discipline in the area. Also, communication learnt through drama rehearsals could considerably influence the way discipline among the students in the region was managed. All-round development acheived through drama rehearsals as well as developing literacy competencies during drama rehearsals could improve the management of students' discipline among secondary school students. Finally, confidence development and intelligence development during drama rehearsals were important to the management of students' discipline among secondary school students in Central Region.

\section{Recommendations}

Through drama rehearsals, institutions will highly enhance language advancement among students. This will improve their communication skills and as a result bring more rapport between the students and administrators. School administrators should also encourage public speaking through social and academic forums.

\section{Conflict of Interest Statement}

The authors of this article whose names appear below hereby certify that they do not hold any affiliations with any financial gaining institution leading to education grants, honoraria or any other interest. They do not intend to benefit from any gainful capacities as a result of this article publication.

Consequently, to the best of our knowledge, this article has not in any way received financial assistance from any source.

\section{Authors' contribution}

Corresponding author: Pachomius Wambugu

Contributing authors: Dr Zachary Ndwiga Njagi \& Dr Rebecca Wachira.

\section{About the Author}

The corresponding author is a PhD candidate at Kenya Methodist University (KeMU), Department of Education pursuing Doctor of Philosophy in leadership and Educational Management. He has also done research and article on Role of Drama Skills in Regulating students' behavior in Secondary Schools in Central Region, Kenya. He has made presentations in different conferences; Philosophy of Drama at Chuka University, Kenya and Applicability of Drama Genres in the Management of Discipline in Secondary Schools in Central Region, Kenya at Kenya Methodist University. 


\section{References}

Alemayehu, T. M. (2012). Assessment of students' misbehavior and coping strategies (in the case of Shashemene secondary school). (MA thesis); Addis Ababa University. Addis Ababa, Ethiopia.

Ali, A., Dada, I., Isiaka, G., \& Salmon, S. (2014).Types, Causes and Management of Indiscipline Acts among Secondary School Students in Shomolu Local Government Area of Lagos State. Journal of Studies in Social Sciences, 8(2), 254-287

Blaya, C. (2012). School climate and violence in French and English secondary education systems, in E. Debarbieux and C. Blaya (eds) Violence in Schools and Public Policies, Paris, Elsevier Science, 141-158.

Boxford S., (2006). Schools and the Problem of Crime, Cullumpton/Devon, Willan Publishing.

Broadhurst, K., Duffin M., \& Taylor E.(2008).Gangs and Schools: Interim Report. An interim report for the NAS/UWT, Leicester, Perpetuity Research and Consultancy International Ltd.

Buchanan, M. (2010). The Importance of Drama in Primary Education. Retrieved fromhttps://www.scribd.com/document/95540286/Drama-in-Education-DIE

Bushaw, W. J., \& Lopez, S. J. (2010). A time for change: The 42nd annual Phi Delta Kappa/Gallup Poll of the public's attitudes toward the public schools. Phi Delta Kappan,92(1), 9-26.

Canter, L. (2009). The behavior management cycle: Retrieved from https://www.achievementfirst.org/

Catteral, J. (2002). Research on drama and theatre in education. Critical Links: Learning in the arts and Student Academic and Social Development. Research Compendium, National Endowment for the Arts. Retrieved from http:/www.aep-arts.org-PDF Files-CL drama

Dalporto, D. (2013). Restorative Justice: A Different Approach to Discipline. We Are Teachers. Retrieved 1 June 2017. http://www.weareteachers.com/restorativejustice-a-different-approach-to-discipline/

Eshetu, A. A. (2014). Indiscipline Problems of High School Students: the Case of EthioJapan Hidasse Secondary School (Addis Ababa, Ethiopia). Journal of Education and Practice, 5(37), 23-28

Formosinho, M., Taborda, M. C., \& Fonseca, A. (2008). Bullying in adolescence: data from Portuguese school. In R. Astor, E. Debardieux, \& C. NETO (Eds). 4th World Conference on Violence in School and Public Policies (p. 33). Lisboa: Edições FMH.

Fuchs, M. (2009). Impact of school context on violence at schools. A multi-level analysis, International Journal on Violence and Schools, 7, 1, 20-42.

Fuchs, M., \& Schmalz, S. (2009). School Violence: Findings of a longitudinal study conducted in Bavaria (Germany), Revista de Reinserção Social e Prova, 2, 1, 43-53.

Gardner, M., Roth, J., \& Brooks-Gunn, 1. (2008). Adolescents' participation in organized activities and developmental success 2 and 8 years after high school: Do 
sponsorship, duration, and intensity matter? Developmental Psychology, 44(3), 814830.

Gitome, J., Katola, M \& Nyabwari, B. (2013). Correlation Between Students' Discipline and Performance in the Kenya Certificate of Secondary Education. International Journal of Education and Research 1(8)

Government of Kenya (2016). Education Report, Students unrest in schools in Kenya, Nairobi, Kenya: Government Printers.

Gottfredson, D. (1985). School Size and Disorder. Centre for Social Organization of Schools, Maryland, USA: Johns Hopkins University.

Gottfredson, G. D. \& Gottfredson, D. C. (1985). Victimization in Schools. New York: Plenum health of elementary schools. School Psychology Quarterly, 23(4), 462-473.

Gyan, E., Baah-Korang, K., McCarthy, P., \& McCarthy, P. (2015). Causes of Indiscipline and Measures of Improving Discipline in Senior Secondary Schools in Ghana: Case Study of a Senior Secondary School in Sunyani. Journal of Education and Practice, 6(11), 19-25

Hayden, C. (2009). Deviance and Violence in Schools a Review of the Evidence in England. International Journal of Violence and School, 9, 7-30

Kajubi, S. W. (2007). Discipline Corporal Punishment and Violence Against Children in the school system. Keynote Address; Public Lecture, 13th June 1997, Makerere University.

Kava Cultural Group Association, (n.d). Drama Improves. Lisbon Key Competences in Education (DICE), Budapest, HU. Retrieved from http://www.dramanetwork.eu/

Kenya Institute of Education (KIE) (2006). Facilitator's handbook on Life skills education, for prevention of drugs and substance abuse. Kenya Institute of Education.

Kenya National Assembly (KNA) (2008). Report of the departmental committee on education, research and technology on the inquiry into students' unrests and strikes in secondary schools. Kenya National Assembly.

Kenya National Drama Festival. (2013). Revised Rules and Regulations. Nairobi. Ministry of Education.

Kenya National Drama Festival. (2016). Revised Rules and Regulations. Nairobi. Ministry of Education.

Kimotho, F., Njoka, J., \& Gitumu, M. (2019, September 17). Effectiveness of Counselors in Managing Discipline in Public Secondary Schools in Kenya: Case of Mt. Kenya East Selected Counties. African Journal of Education, Science and Technology, 5(2), Pg 220-228. Retrieved from http://ajest.info/index.php/ajest/article/view/369

Lipman, M. (2002). Interview. Critical \& Creative Thinking: The Australasian Journal of Philosophy for Children.

Masitsa, G. (2008). Discipline and disciplinary measures in the free state Township schools: Unresolved problems. Acta Academia 40 (3), 234-270.

Mbiti, D. M. (2007). Foundations of school administration. Nairobi: Oxford University Press, East African Ltd. 
McMaster, J. C. (1998). “Doing” Literature: Using Drama to Build Literacy. The Reading Teacher, 574-584. (EJ562451). https://www.jstor.org/stable/20201964

Ministry of Education Science and Technology (MOEST) (2000). Report on Causes, Effects and Remedies of indiscipline in Secondary Schools in central province. MOEST.

Ministry of Education Science and Technology (MOEST) (2001). Report of the task force on student discipline and unrest in secondary schools. Wangai Report, Jomo Kenyatta Foundation.

Ministry of Education Science and Technology (MOEST) (2008). Elimu News. Ministry of Education, Jogoo House.

Ministry of Education Science and Technology (MOEST) (2009). Elimu News. Unpublished

Nakpodia, E. D. (2010). Teachers' disciplinary approaches to students' problems in Nigerian secondary schools. International NGO Journal, 5(6). Accessed 2 December, 2018.

Ncube, B. (2013). Parental involvement in school discipline. Harare, College Press.

Ndagire, B. (2012). Management of Students Discipline in Private Secondary schools in Entebbe Municipality. A Dissertation directed to the Directorate of Research. Kampala. Uganda: Makerere University.

Ngigi, F. (2010, October 19). Not Again! Tragedy: Two parish as students' torch dormitory. The standard, pp1,8.

Ngugi, G. M. (2007). Factors Contributing to Students Indiscipline and Unrest in Secondary Schools in Maragua District. Unpublished Masters' Thesis. Egerton University

Ngunyi, J. C. (2014). Influence of Alternative Disciplinary Measures on Students' Discipline in Public Secondary Schools in Nyandarua South Sub - County, Kenya. (Unpublished Masters Thesis), University of Nairobi

Ngwokabuenui, P. Y. (2015). Students' Indiscipline: Types, Causes and Possible Solutions: The Case of Secondary Schools in Cameroon. Journal of Education and Practice, 6(22), 64-72

Obidike, N. D. (2004). Development and validation of disciplinary management skill assessment scale for principals in Anambra State. Unpublished $\mathrm{PhD}$ thesis Nnamdi Azikiwe University, Awka.

Okone, S. (2016). Analysis of the Banning of Corporal Punishment With Specific Reference To Mill's Theory Of Utilitarianism: A Case Of Secondary Schools In Kisii Central Sub-County, Kenya. Unpublished Thesis, Egerton University

Okumu, M. O. (2014). An Investigation of Factors Influencing Indiscipline Among Students in Public Day Secondary Schools in Makadara District, Nairobi County. Unpublished Thesis, Kenyatta University

Oluremi F. D. (2013).Truancy and Academic Performance of Secondary School Students in Southwestern Nigeria: Implications for Counseling. International Journal for Cross-Disciplinary Subjects in Education; 3(2): 1424-1428. 
Ouma, M. A., Simatwa, E. M., \& Serem, T. (2013). Management of pupil discipline in Kenya: A Case Study of Kisumu Municipality. Educational Research, 4(5), 21415161.

Republic of Kenya (2012). Reforming Education and Training Sectors in Kenya. Sessional Paper No. 14 of 2012, Nairobi: Government Printers.

Simatwa, E. M. W. (2012). Management of Students' Discipline in secondary schools in Kenya, a case study of Bungoma County. Educational Research 3(2)172 - 189. Retrieved from https://www.interesjournals.org/.

Tan, E., \& Yuansha, C. (2014). Discipline problems in schools: teachers' perception. Teaching and Learning 19(2): 1-12.

Ulas, A. H. (2008). Effects of Creative, Educational Drama Activities on Developing Oral Skills in Primary School Children. American Journal of Applied Sciences. 5 (7): 876880,2008. Retrieved from https://thescipub.com/html/10.3844/ajassp.2008.876.880

Wanyama, C. (2006). Kenyan schoolgirls raped on March: at least 15 schoolgirls in Kenya were raped during a night-time protest march in the central district of Nyeri. British Broadcasting Corporation News.

Wasambo, W. (2014). A Traditional Ritual ceremony as Edurama: A case study of Imbalu ritual among the Bukusu of western Kenya, Kenya: Kenyatta University. 
Wambugu Pachomius, Zachary Njagi Ndwiga, Rebecca Wachira to copy, distribute, transmit or adapt the article content, providing a proper, prominent and unambiguous attribution to the authors in a manner that makes clear that the materials are being reused under permission of a Creative Commons License. Views, opinions and conclusions expressed in this research article are views, opinions and conclusions of the author(s). Open Access Publishing Group and European Journal of Education Studies shall not be responsible or answerable for any loss, damage or liability caused in relation to/arising out of conflicts of interest, copyright violations and inappropriate or inaccurate use of any kind content related or integrated into the research work. All the published works are meeting the Open Access Publishing requirements and can be freely accessed, shared, modified, distributed and used in educational, commercial and non-commercial purposes under a Creative Commons Attribution 4.0 International License (CC BY 4.0). 